\title{
EFFECT OF HEAVY METALS ON SOME PHYSIOLOGICAL RESPONSES IN TWO FISH SPECIES INHABITING MEDITERRANEAN SEA COAST; DAMIETTA GOVERNORATE, EGYPT.
}

Mohamed Hamed Ghanem

Department of Zoology, Faculty of Science, Al-Azhar University.

\begin{abstract}
The present study aims to determine the concentrations of heavy metals: Cadmium, Copper, Iron, Nickel, Lead and Zinc in the two fish species, Sparus aurata and Diplodus sargus, (family: Sparidae) collected from the Mediterranean Sea Coast, Damietta Governorate, in order to: compare concentrations of metals in the different organs (gonads, kidney, liver, muscles, gills, skin and bones) and their effects on the physiological parameters (total proteins, total lipids, ASAT and ALAT) in the edible organs of these species.

Results revealed that, the highest values of heavy metals in the different organs of S. aurata and D. sargus were recorded during summer. Although, the two species have the same behavior of feeding, S. aurata showed high values of the different metals than D. sargus. Biochemical analysis indicated devastating effects in metabolic parameters and enzymes activities in S. aurata than D. sargus. ANOVA ( $p>0.05)$ showed significant differences between the different organs and metals. Also, biochemical parameters exhibited a significant increase between seasons and the different organs and a slight difference between the studied fishes.
\end{abstract}

Key words: Heavy metals, biochemical parameters, Sparus aurata and Diplodus sargus.

\section{INTRODUCTION}

The contamination of aquatic systems with a wide range of pollutants has become a matter of concern since the last few decades (Canli et al., 1998; Dirilgen, 2001; Vutukuru, 2005; Amaraneni, 2006; Rao and Rao, 2007; Vinodhini \&Narayanan, 2008 and Gupta et al., 2009). The natural water bodies may extensively be contaminated with various heavy metals released from industrial and mining effluents, combustion of fossil fuels, discharge of sewage and sewage sludge; fertilizers and residues of domestic $\&$ pesticides, dumping of hospital and anthropogenic activities, etc. (Forstner and Wittmann 1979; Conacher et al., 1993; Velez and Montora, 1998; Chandra-Sekhar et al., 2004; Vinodhini \& Narayanan, 2008; Malik et al., 2010 and LaxmiPriya et al., 2011). Heavy metal contamination may cause devastating effects on the ecological balance of the recipient environment and its diversity of aquatic organisms (Ashraj, 2005; Vosyliene \& Jankaite, 2006; Farombi et al., 2007 and Vinodhini \& Narayanan, 2008).

Traces of heavy metals, such as Copper and Zinc play a biochemical role in the life processes of some aquatic plants and animals while it become toxic when it is present at high concentrations (Kotickhoff, 1983). Fish are often the top of aquatic food chain and is an important source of protein for human which may absorb large amounts of some metals such as Cadmium, Copper, Iron, Nickel, Lead and Zinc through epithelial or mucosal surface of the skin, gills and gastrointestinal tract. These metals accumulate differently in the fish organs (liver, kidney, muscles, gonads and brain) and caused health problems for fish consumers (Wallaert and Bobin, 1994). Low concentrations of heavy metals may not kill individuals of the fish affect on their size, reproduction and body weights, thus reducing their ability to compete for food and habitat which affect directly on the metabolic and enzymes activities correlated with changes in the rate of protein synthesis (Gomaa et al., 1995a\&b; Fayed et al., 2001; Vosyliene \& Jankaite, 2006; Badmus et al., 2007and Jovanovic et al., 2011).

Some heavy metals are the most uncertain environmental pollutants such as Cadmium which is toxic for living organisms. It is mostly used in manufacturing of batteries, pigments and also in plastic industries (ATSDR, 1997), thus its toxicity at low level causes poisoning in various tissues which induce kidney, liver, gills and heart malfunctioning. Heavy metals have badly influence on blood parameters in living organism and lead to hematological disorders and cause oxida- 
tive stress and may due to devastating effects on cell components (McCluggage, 1991; European Union, 2002; Jarup, 2003; Yadav \& Khandelwal, 2005; Young, 2005 and Yapici et al., 2006). The trace metals are uptake more rapidly at high temperature by marine organisms (Raymont and Shields, 1994).

Muscles is one of the most organs which are varied in composition according to the species, sex and maturity as well as seasons (Rubbi et al., 1985). Biochemical and physiological biomarkers are frequently used for detecting or diagnosing the harmful effects in fish exposed to different toxic substances. Transaminase enzymes play a vital role in carbohydrate and protein metabolism in fish and other organism's tissues (Eze, 1983). Changes in enzymes activity and other biomarkers have been studied as possible tools for aquatic toxicological research (Moore and Simpson 1992; Arellano et al, 2000 and Abou El-Naga et al., 2001). Therefore, in the present study attempts have been made to assess the heavy metals concentrations in the fishes caughted from Damietta Coast and their effects on biochemical parameters in the different organs of the two important commercial species.

\section{MATERIALS AND METHODS}

\section{- Specimens collection:}

A total of 42 specimens of sparid fishes, Sparus aurata and Diplodus sargus were collected during winter and summer, 2014 for the present study. Gill net and encircling net were the main fishing methods used to collect the fish samples. After collection however possible, fishes were freshly examined or immediately preserved in an ice box and transferred to the laboratory for latter examination. In the laboratory, standard and total length of each fish were measured to the nearest centimeter and recorded, while the body weight was determined to the nearest gram. Then, each fish was dissected and the internal organs and muscles were separated and treated as the following:

\section{- Heavy metals determination in the tissues:}

Equal amounts $(15 \mathrm{ml})$ of concentrated nitric acid, hydrofluoric acid and perchloric acid were added to $0.5 \mathrm{gm}$ of each tissue into Teflon beaker. The latter was covered, set aside for several hours, and evaporated to a few drops. $5 \mathrm{ml}$ of
$\mathrm{HCIO} 4$ were added again and evaporated just to dryness. After addition of $10 \mathrm{ml}$ of concentrated $\mathrm{HCl}$, beaker was placed back on a hot plate until the solution becomes clear. Deionized distilled water was added and the digested material was filtered, then residue washed several times with deionized distilled water and complete to $100 \mathrm{ml}$ volumetric flask.

Heavy metals were analyzed by atomic absorption model Perkin Elmer 3150. Concentrations were expressed into $\mu \mathrm{g} / \mathrm{gm}$ tissue according to APHA (1992).

\section{- Physiological studies:}

After the dissection of the collected fishes, a known weight of the target organs (liver, kidney, gonads and muscles) was homogenized by using the electric homogenizer for $2 \mathrm{~min}$. The homogenated specimens were centrifuged at 4000 r.p.m. for $15 \mathrm{~min}$. at $2 \mathrm{C}^{\circ}$ in a refrigerator centrifuge. The supernatant solution was used directly or stored at $4 \mathrm{C}^{\circ}$ until the use for the biochemical analysis.

Total protein content of the different organs was determined according to Doumas Method (1975), while total lipids was detected according to the method of Knight et al., (1972) by using a kit of Bioadwic Company. Enzymes activities were measured according to the method of Reitman and Frankel (1957) by using a kit of Bioadwic Company.

\section{- Statistical analysis:}

Results were expressed in tables as mean \pm S.D. Data were analyzed by using analysis of variance (ANOVA) according to Bailey (1981).

\section{RESULTS AND DISCUSSION}

\section{$\S$ Heavy metals determinations:}

The present study attempts to create awareness concerning the potential severe public health issues resulting from the toxic effects of heavy metals as pollutants from different sources. The toxic effects of heavy metals on fish involve hepatotoxicity, neurotoxicity and nephrotoxicity (Valko et al., 2005). Bioaccumulation of heavy metals and consequent alterations in gills, liver, kidney and flesh of the two species were examined. Results (Tables $1 \& 2$ and Figures $1 \& 2$ ) indicated that, the highest values of heavy metals (Cadmium, Copper, Iron, Nickel, Lead and Zinc) 
Effect of heavy metals on some physiological responses in two fish species

in the gonads of $S$. aurata and D. sargus were observed during summer than the winter with maximal values $(34.55 \pm 6.20$ and $20.13 \pm 8.14$ $\mu \mathrm{g} / \mathrm{g}$ wet $\mathrm{wt}$, respectively) for Iron concentration while the minimal values $(1.65 \pm 0.43$ and $1.11 \pm$ $0.30 \mu \mathrm{g} / \mathrm{g}$ wet wt, respectively) were detected for Cadmium concentration.

Kidney is one of the most important metabolic organs which can accumulate large quantities of metals than the other organs. Kidneys of the two species showed the same trend with high peak for Iron level in S. aurata followed by Zinc ions during summer and winter, respectively; being $145.00 \pm 7.10$ and $130.03 \pm 4.60 \mu \mathrm{g} / \mathrm{g}$ wet wt in the former and $60.23 \pm 4.11 \& 56.08 \pm 3.50 \mu \mathrm{g} / \mathrm{g}$ wet $\mathrm{wt}$, respectively in the latter. It showed a depletion concentration $(1.00 \pm 0.07 \mu \mathrm{g} / \mathrm{g}$ wet wt $)$ during winter in Copper ion than the other metals. Kidney of $D$. sargus, showed the highest values of Iron ion concentration followed by Zinc ion during summer and winter, respectively; being $122.50 \pm 8.90$ and $114.10 \pm 6.71 \mu \mathrm{g} / \mathrm{g}$ wet wt in the former and $57.22 \pm 8.50 \& 50.60 \pm 6.50 \mu \mathrm{g} /$ $\mathrm{g}$ wet wt, respectively in the latter. The highest value copper ion concentration $(0.50 \pm 0.11 \mu \mathrm{g} / \mathrm{g}$ wet wt) was recorded during winter (Tables $1 \& 2$ and Figures $3 \& 4$ ).

Liver plays an important role in the detoxification and toxicants storage, and this explains the high levels of heavy metals in this organ. A1though, the two species in the present study have the same feeding behavior, $S$. aurata showed high values of the different metals than $D$. sargus. Results (Tables $1 \& 2$ and Figures 5\&6) exhibited that, the maximum values of the heavy metals in livers of $S$. aurata and D. sargus were recorded for Iron ion during summer; being $103.00 \pm 14.30$ and $94.15 \pm 9.20 \mu \mathrm{g} / \mathrm{g}$ wet wt, respectively, while the lowest values $(1.60 \pm 0.20$ and $0.70 \pm 0.21 \mu \mathrm{g} / \mathrm{g}$ wet $\mathrm{wt}$ ) were measured during winter, respectively, in the two species for cadmium concentration.

Muscle compositions are varied according to the species, sex and maturity as well as seasons (Rubbi et al., 1985). Data in Tables (1\&2) and Figures $(7 \& 8)$ revealed that, heavy metals concentration in the muscles of $S$. aurata were fluctuated between $1.75 \pm 0.63 \mu \mathrm{g} / \mathrm{g}$ wet wt for Copper ions during winter and $44.09 \pm 0.12 \mu \mathrm{g} / \mathrm{g}$ wet wt for Iron ions during summer. On the other hand, determination of heavy metals in the muscles of $D$. sargus exhibited that, they were varied from $0.50 \pm 0.12 \mu \mathrm{g} / \mathrm{g}$ wet wt for Copper ion and $0.50 \pm 0.11 \mu \mathrm{g} / \mathrm{g}$ wet wt for Lead ion concentrations during winter to $28.40 \pm 6.44 \mu \mathrm{g} / \mathrm{g}$ wet wt for Iron ion during summer.

It is well known that, heavy metals are taken up by the fish directly from the water, especially by gills (Skidmore, 1964). The present study (Tables 1\&2 and Figures 9 \&10) indicated that, gills are the more organs affected by contaminants. The highest peak of heavy metals in the gills of $S$. aurata was recorded during summer for Iron ion concentrations and the depletion was observed during winter in the Copper ions; being $119.03 \pm 6.14$ and $1.65 \pm 0.22 \mu \mathrm{g} / \mathrm{g}$ wet $\mathrm{wt}$, respectively. Regarding gills of $D$. sargus, it exhibited the highest value $(64.88 \pm 6.25 \mu \mathrm{g} / \mathrm{g}$ wet wt) during summer for iron ion and the lowest $(1.10 \pm 0.10 \mu \mathrm{g} / \mathrm{g}$ wet wt) during winter for copper ion concentration. Concentrations of heavy metals in the skin of $S$. aurata and D. sargus during summer showed a slight high values than the winter. Results indicated that, the concentration of iron ions during summer in the skin of the two species was the higher compared with other metals and the lower values were observed during winter for the copper; being $94.12 \pm 6.25$ $\& 43.56 \pm 7.14 \mu \mathrm{g} / \mathrm{g}$ wet $\mathrm{wt}$, respectively in the former and $1.80 \pm 0.30 \& 0.50 \pm 0.13 \mu \mathrm{g} / \mathrm{g}$ wet $w t$, respectively in the latter (Tables $1 \& 2$ and Figures 11\&12).

On contrast to all results of iron concentration in the previous organs, a sharp decline in Iron levels was detected in bone of $S$. aurata during both summer and winter. Results declared that, heavy metals concentrations in the bones of $S$. aurata, was ranged between $1.65 \pm$ $0.21 \mu \mathrm{g} / \mathrm{g}$ wet wt during winter for Copper ions and $28.14 \pm 6.81 \mu \mathrm{g} / \mathrm{g}$ wet wt during summer for Zinc ions. In D. sargus, however, the maximum value of heavy metals concentration in the bones was recorded during summer for Iron ion and the minimum value was observed during winter for the Copper; being $33.10 \pm 6.16$ in the former and $1.50 \pm 0.34 \mu \mathrm{g} / \mathrm{g}$ wet wt in the latter (Tables $1 \& 2$ and Figures 13\&14).

Although some heavy metals are essential 
elements at low concentrations for many organisms; it becomes toxic at the higher concentrations (Clark and Keasling, 2002 and Faria et al. 2010). From the above findings, it can be concluded an increasing of heavy metals in the different organs of $S$. aurata than that in D. sargus. Iron ion concentration exhibited a high level in all organs along the study period except the bone of $S$. aurata showed a higher level of Zinc during the two seasons; this may be due to the increase of heavy metals in the drainage waters, decomposition of organic matter and discharge remnants of fertilizer factories and other chemicals lead to this fact, the uptake of metals is influenced by many factors including fish species, age, type of fish organs, season and various environmental factors. This findings agree with Badsha \& Goldspink (1982\&1988); Gomaa et al. (1995a\&b); Nagdi \& Shaker (1998); Ptashynski \& Klaverkamp (2002); El-Serafy et al. (2003a) and Ghanem (2006\&2011) whom attributed the increase of metals during hot seasons to the effect of temperature and winds on the solubility and distribution of these metals and differ with Yacoub and Gad (2012) whom reported that, cold season exhibited the high level of these metals than the hot one. Also, Said \& El-Agroudy (2003) and El-Serafy et al. (2003b) mentioned that, no marked seasonal variations in the concentration of metals in Patella Caerulea lived in polluted area of Alexandria Coast were detected.

Results indicated that, the heavy metals accumulate mainly in the gills and metabolic organs such as liver that stores metals to be detoxificated as its main function by production metallothionein. Similar observations were in agreement with Kargin \& Erdem (1991); Zyadah (1995); Ahmed \& Al-Ghais (1996); Adeyeye et al.(1996); Shakweer \& Abbas (1997); Ibrahim et al. (1999 a\&b); Ghanem (2006\&2011) and Jovanovic et al. (2011) whom reported that, the differences of heavy metals concentrations in the fish organ were related to their tendency of absorption and accumulation of heavy metals through epithelial, mucosal surface, gastrointestinal tract, metabolic organs with relation to their mode of living and feeding behaviour.

In the present study, the concentrations of heavy metals were increased during summer than winter; this may be attributed to the low water level and the inefficient removal of trace metals by organisms or to the low degree of nutrient recycling and to the discharge of sewage, industrial wastes and paints into this location. This finding are agree with UNEP (1993) and Abdel-Monem et al. (1994) whom stated that, the concentration of heavy metals may be associated with high trophic level predators, filter and bottom feeder with increased consumption of particulate matter along with absorbed metals.

The present results showed high concentration in some heavy metals than the other indicated to the lower values of one metal accompanied by high concentration of other in the same season, this may be due to the fact that, the presence of one metal deletes or reduce the accumulation of another metal. Similar observation was detected by El-Sharnouby et al. (1986); Cossa et al. (1992) and Ghanem (2006\&2011).

\section{§ Biochemical parameters:}

The present study (Table 3 and Figures $15 \& 16)$ revealed that, total proteins in the different organs of $S$. aurata, attained its highest value $(208.46 \pm 15.90 \mathrm{mg} / \mathrm{g}$ wet wt) in the muscles during winter. It decreased gradually in the gonads and kidney during winter $(124.76 \pm 22.50$ and $112.16 \pm 7.80 \mathrm{mg} / \mathrm{g}$ wet wt, respectively) and reached its lowest value $(96.17 \pm 12.40 \mathrm{mg} / \mathrm{g}$ wet wt) in the liver during summer. Concerning $D$. sargus, it was varied from $100.64 \pm 6.55 \mathrm{mg} / \mathrm{g}$ wet $w t$ in the kidney during summer to $204.33 \pm 10.56$ $\mathrm{mg} / \mathrm{g}$ wet wt in the muscles during winter.

The lowered levels of protein in the fish organs during summer may be due to metabolic adaptation to food shortage in the environment. This finding was agreed with White et al. (1986) and Haggag et al. (1999) whom stated that, during the period of inadequate food supply, energy required for metabolic maintenance may be provided from utilization of protein reserves which mainly accumulate in the muscle and metabolic tissues. In addition, protein depletion could be attributed to change in the water quality as a result of the discharged effluents from different sources (Zaghloul, 2000). This may be explained that the exposure to metals may lead to high accumulation in gills that cause a structural damage and a reduction in oxygen consumption 
causing sharp reduction in the metabolic rate of fish and consequently decrease protein contents in tissues.

Total lipids in the different organs of $D$. sargus are slightly increased during the study period than $S$. aurata, with increasing during winter compared with summer. Data in Table (3) and Figures (17\&18) mentioned that, the maximum values of total lipids for the samples of $S$. aurata were recorded during winter in the muscles and liver $(30.46 \pm 4.36$ and $28.60 \pm 4.54 \mathrm{mg} / \mathrm{g}$ wet wt, respectively) while the minimum values were determined during summer in the gonads and kidneys; being $14.79 \pm 7.90 \mathrm{mg} / \mathrm{g}$ wet wt in the former and $16.88 \pm 2.49 \mathrm{mg} / \mathrm{g}$ wet wt in the latter. At D. sargus, however, it was varied from $18.20 \pm 7.30 \mathrm{mg} / \mathrm{g}$ wet wt during summer in the gonads to $34.66 \pm 2.40 \mathrm{mg} / \mathrm{g}$ wet wt during winter in the muscles. The depletion in total lipids in the different organs during summer than the winter may be due to the use of energy-rich lipids for energy production during toxic stress. Similar observations were recorded by Sancho et al. (1998); Chandra et al. (2004) and Blaner et al. (2005).

Aspartate aminotransferase (ASAT) in the two species, S. aurata and D. sargus exhibited the highest values during summer in the liver and gonads; being $530.22 \pm 4.76 \& 480.26 \pm 8.46$ $\mathrm{U} / \mathrm{g}$ wet $\mathrm{wt}$, respectively in the first species and $476.36 \pm 7.46 \& 425.32 \pm 10.88 \mathrm{U} / \mathrm{g}$ wet $w t$, respectively in the second one. While, the lowest values of ASAT were detected in the muscles of two species, $S$. aurata and D. sargus during winter; being $306.17 \pm 27.56 \mathrm{U} / \mathrm{g}$ wet wt and $248.58 \pm 18.33 \mathrm{U} / \mathrm{g}$ wet wt) (Table, 3 and Figures 19\&20). Alanine aminotransferase (ALAT) in the collected fishes, S. aurata and D. sargus exhibited the higher levels during summer in the liver and gonads $(338.40 \pm 16.72 \& 364.20 \pm 15.63$ $\mathrm{U} / \mathrm{g}$ wet wt, respectively in the first species and $325.61 \pm 5.63 \& 342.62 \pm 26.10 \mathrm{U} / \mathrm{g}$ wet wt, respectively in the second one). While, the lowest values of ALAT (218.53 \pm 17.82 and $207.17 \pm 14.76 \mathrm{U} / \mathrm{g}$ wet $\mathrm{wt}$ ) were measured during winter, respectively in the muscles of two species (Table, 3 and Figures 21\&22).

The present study revealed that, ASAT and ALAT activities in all examined organs are relatively increased during summer. This find- ing agree with those observed by Cullen et al. (2003) whom reported that, enzyme activity appeared to increases during the summer season. The present study showed an increase in ASAT and ALAT activities in the liver, kidney and gonads of the two species examined. Such elevation might reflect the early toxic effects of heavy metals on the hepatic enzyme activities. Similar observations have been reported by many authors notably Oluah (1998); Oluah (1999); Zikic et al. (2001); Rao (2006) and Ghanem (2006\&2011) and differ with Shakoori et al. (1990); Begum \& Vijayaragharan (1995); Abu El-Ella (1996); Zaghloul (1997); Salah El-Deen et al. (2000) and Shalaby (2000) whom declared that, the decrease of ASAT and ALAT in the liver and muscles may be attributed to a number of reasons such as leakage from liver and muscles into the blood, actual liver and muscles enzymes inhibition by the effect of toxicant, disturbance in Kreb's cycle and damage of liver and kidney cells (necrosis) that affect the membrane permeability which in turn liberate the enzymes to extra-cellular fluid and blood. On the other hand, the opposite effects on hepatic ASAT and ALAT activities might be due to the liver necrosis induced by toxicants.

Concerning the effect of different pollutants on physiological parameters of the studied fish, results showed significant differences between the different organs and metals. Also, biochemical parameters exhibited a significant increase between seasons and the different organs. A slight difference between the two studied species was also recorded.

- Results recommended that, treatment of drainage industrial wastes water, sewage and other sources of metals must be conducted before discharge into the study area. The advisable for public health that human must be use only muscles of fish for food and that the internal organs must not be used as fish meal for other purposes. Also, it is advisable for public health that human must eat the fish during winter and avoid eating them at the summer which contains high concentrations of heavy metals. This is may be due to that the fish can regulate its biochemical properties at the less polluted seasons. Making a research lab with latest scientific techniques to monitor any defect in the physiology of the fish, which in turn affects human health. 


\begin{tabular}{|c|c|c|c|c|c|c|c|}
\hline \multirow{2}{*}{ 鵕 } & 离 & 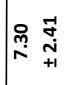 & 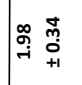 & 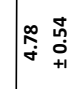 & 号 & 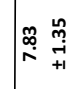 & 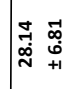 \\
\hline & 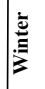 & 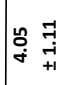 & 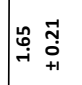 & 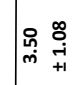 & 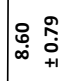 & $\stackrel{\leftrightarrow}{\leftrightarrow} \underset{++1}{\infty}$ & 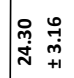 \\
\hline \multirow{2}{*}{$\frac{\bar{z}}{\bar{n}}$} & 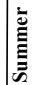 & 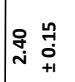 & 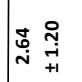 & 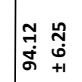 & 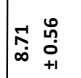 & 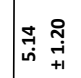 & 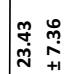 \\
\hline & 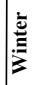 & 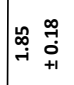 & 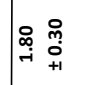 & 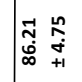 & 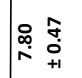 & 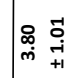 & 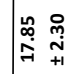 \\
\hline \multirow{2}{*}{ 告 } & 离 & 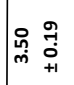 & 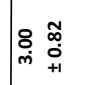 & 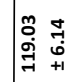 & 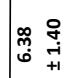 & 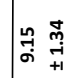 & 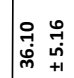 \\
\hline & 离 & 点 & 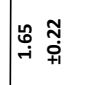 & 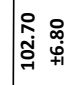 & 兽 & 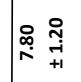 & 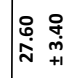 \\
\hline \multirow{2}{*}{ 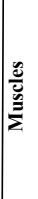 } & 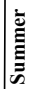 & 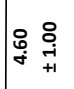 & 总 & 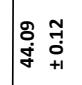 & ஓ & 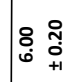 & 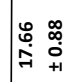 \\
\hline & 悹 & 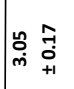 & 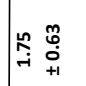 & 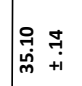 & 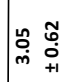 & 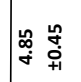 & 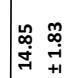 \\
\hline \multirow{2}{*}{ 产 } & 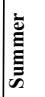 & ت्ञ & 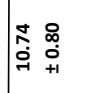 & 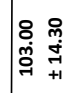 & 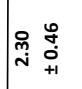 & 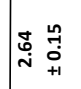 & 节 \\
\hline & 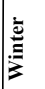 & 華 & 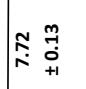 & 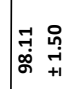 & 官 & 号 & 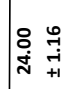 \\
\hline \multirow{2}{*}{ 离 } & 离 & 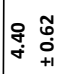 & 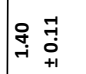 & 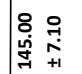 & 总辛 & 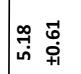 & 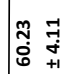 \\
\hline & 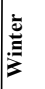 & 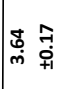 & 号 & 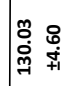 & 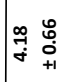 & 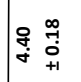 & 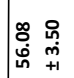 \\
\hline \multirow{2}{*}{ 总 } & 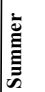 & 号 & 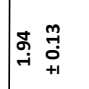 & 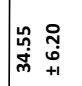 & 莣 & 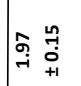 & 宓 \\
\hline & 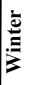 & 華 & 寓 & 赵 & 萧 & 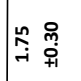 & 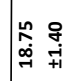 \\
\hline 量 & 号 & $\Xi$ & $\Xi$ & $\leftleftarrows$ & $\bar{z}$ & $\stackrel{\Xi}{\approx}$ & s \\
\hline
\end{tabular}

\begin{tabular}{|c|c|c|c|c|c|c|c|}
\hline \multirow{2}{*}{ 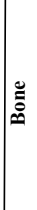 } & 高 & 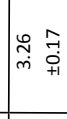 & 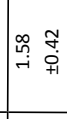 & 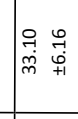 & $\mid \begin{array}{ll}0 \\
0 \\
0 \\
0\end{array}$ & 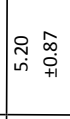 & $\mid$ \\
\hline & 妾 & 足 & 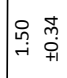 & $\mid \begin{array}{l}\stackrel{0}{\infty} \\
\substack{\infty \\
\sim}\end{array}$ & 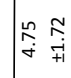 & 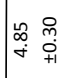 & 峁 \\
\hline \multirow{2}{*}{$\frac{5}{\frac{5}{n}}$} & 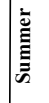 & †ُ & $\mid$ & 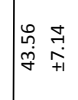 & 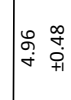 & 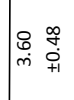 & 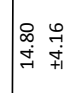 \\
\hline & 竎 & 絖 & 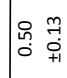 & 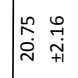 & 密 & 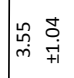 & 絖 \\
\hline \multirow{2}{*}{ 煎 } & 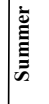 & 峁 & 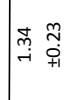 & 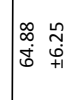 & 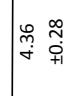 & 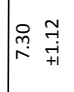 & $\mid$ \\
\hline & 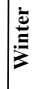 & 号 & 웅 & 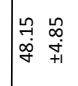 & ه্ণ & 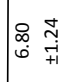 & 总 \\
\hline \multirow{2}{*}{ 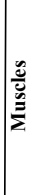 } & 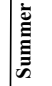 & 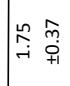 & 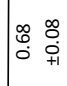 & 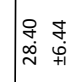 & 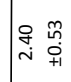 & 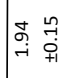 & 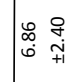 \\
\hline & 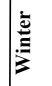 & 学 & 总 & 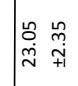 & 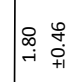 & 总 & 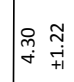 \\
\hline \multirow{2}{*}{ 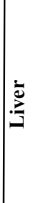 } & 彥 & 韋告 & 敢 & 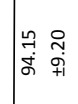 & 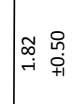 & 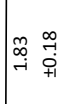 & 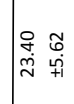 \\
\hline & 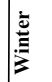 & 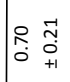 & 记 & 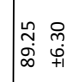 & 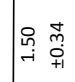 & 足 & 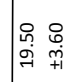 \\
\hline \multirow{2}{*}{ 递 } & 育 & 总 $\begin{array}{c}0 \\
\text { mi }\end{array}$ & \begin{tabular}{ll} 
& $\infty$ \\
0 & 0 \\
0 & 0 \\
\hdashline
\end{tabular} & 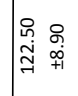 & 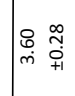 & 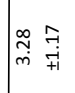 & 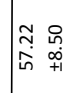 \\
\hline & 彦 & 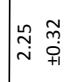 & 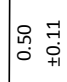 & 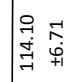 & 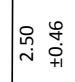 & 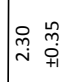 & 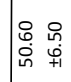 \\
\hline \multirow{2}{*}{ 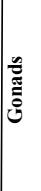 } & 㕍 & 亲 & 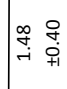 & 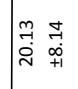 & 节 & 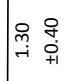 & 家 \\
\hline & 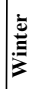 & 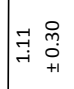 & 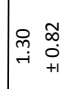 & 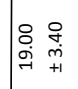 & 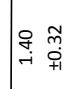 & 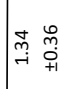 & 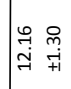 \\
\hline 鵕 & 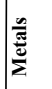 & $\Xi$ & $z$ & $\leftleftarrows$ & z & $\stackrel{a}{a}$ & $\overline{\mathrm{s}}$ \\
\hline
\end{tabular}


Effect of heavy metals on some physiological responses in two fish species

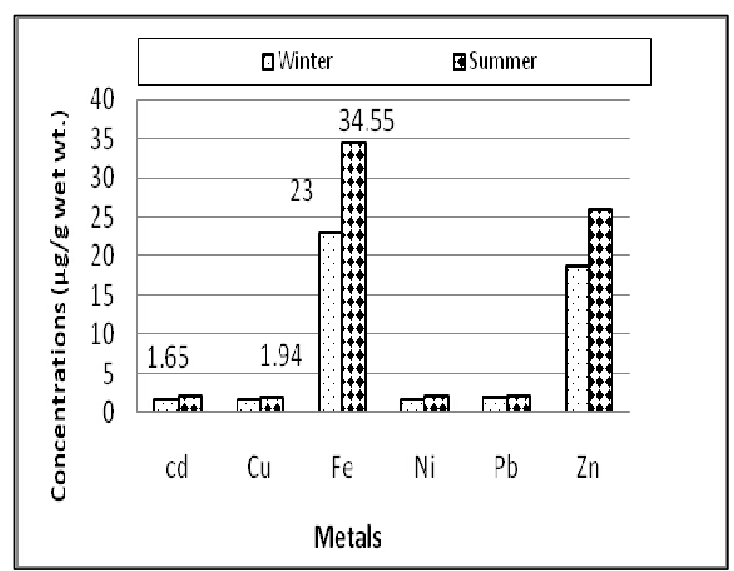

Fig. (1): Concentration of heavy metals $(\mu \mathrm{g} / \mathrm{g}$ wet $w t)$ in the gonads of Sparus aurata, collected from Mediterranean Sea Coast, Damietta Governorate, during winter and summer, 2014.

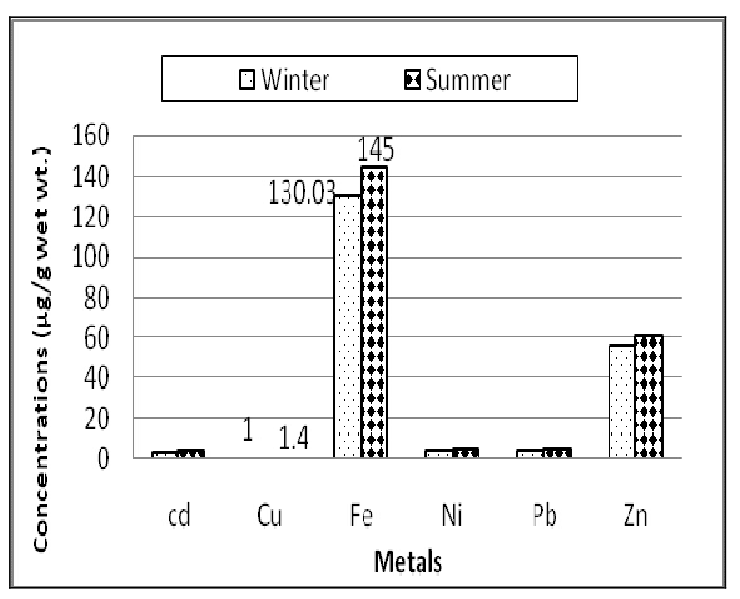

Fig. (3): Concentration of heavy metals ( $\mu \mathrm{g} / \mathrm{g}$ wet $\mathrm{wt})$ in the kidney of Sparus aurata, collected from Mediterranean Sea Coast, Damietta Governorate, during winter and summer, 2014.

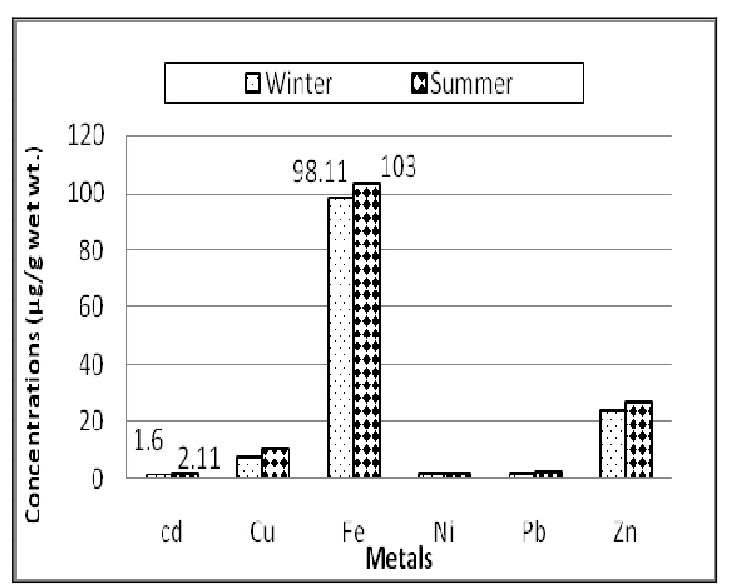

Fig. (5): Concentration of heavy metals ( $\mu \mathrm{g} / \mathrm{g}$ wet $w \mathrm{t})$ in the liver of Sparus aurata, collected from Mediterranean Sea Coast, Damietta Governorate, during winter and summer, 2014.

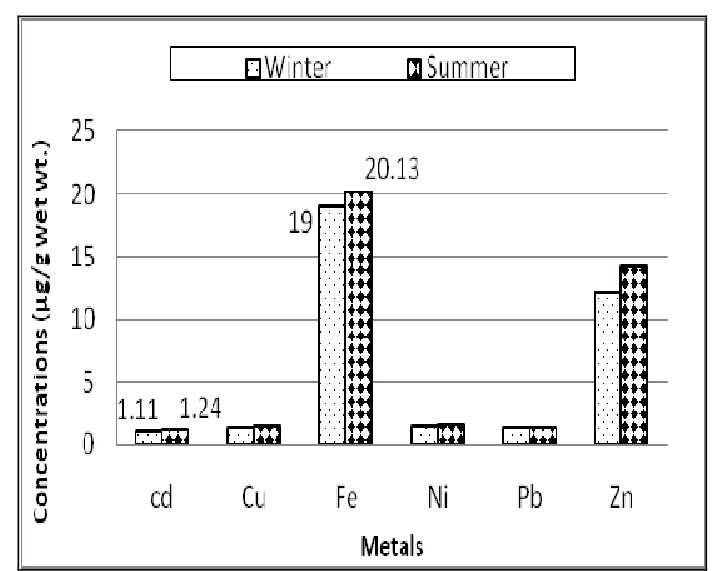

Fig. (2): Concentration of heavy metals ( $\mu \mathrm{g} / \mathrm{g}$ wet $w \mathrm{t})$ in the gonads of Diplodus sargus, collected from Mediterranean Sea Coast, Damietta Governorate, during winter and summer, 2014.

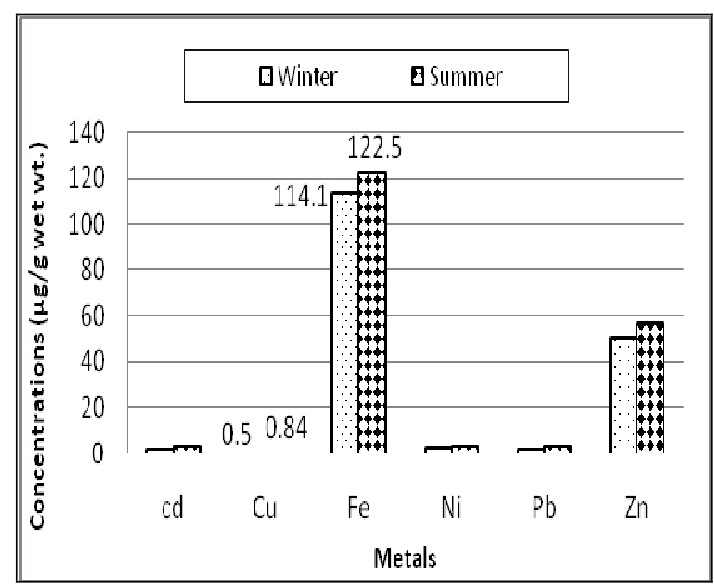

Fig. (4): Concentration of heavy metals ( $\mu \mathrm{g} / \mathrm{g}$ wet $w t)$ in the kidney of Diplodus sargus, collected from Mediterranean Sea Coast, Damietta Governorate, during winter and summer, 2014.

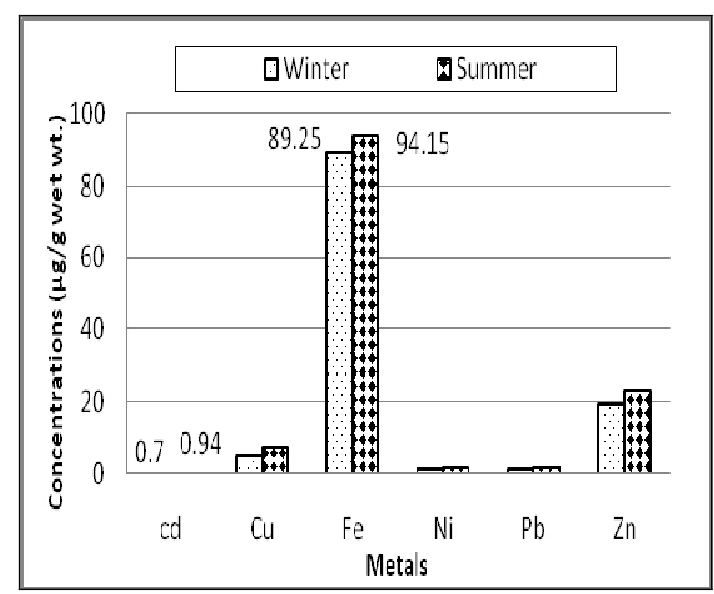

Fig. (6): Concentration of heavy metals ( $\mu \mathrm{g} / \mathrm{g}$ wet wt) in the liver of Diplodus sargus, collected from Mediterranean Sea Coast, Damietta Governorate, during winter and summer, 2014. 
Mohamed Hamed Ghanem

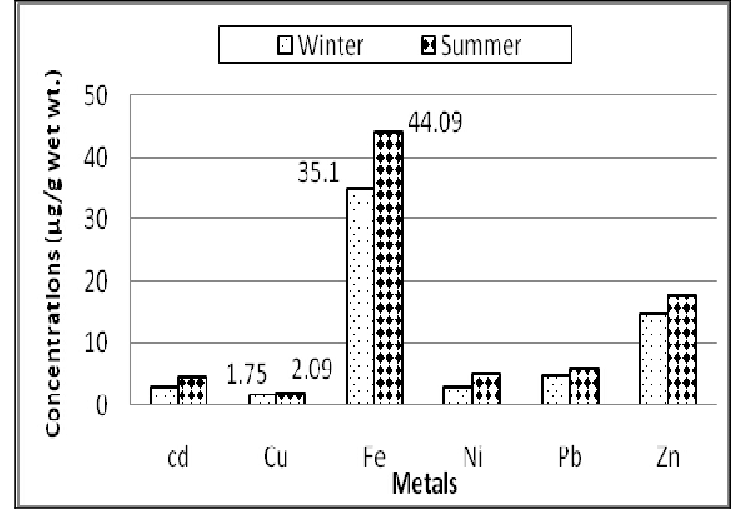

Fig. (7): Concentration of heavy metals $(\mu \mathrm{g} / \mathrm{g}$ wet $\mathrm{wt})$ in the muscles of Sparus aurata, collected from Mediterranean Sea Coast, Damietta Governorate, during winter and summer, 2014.

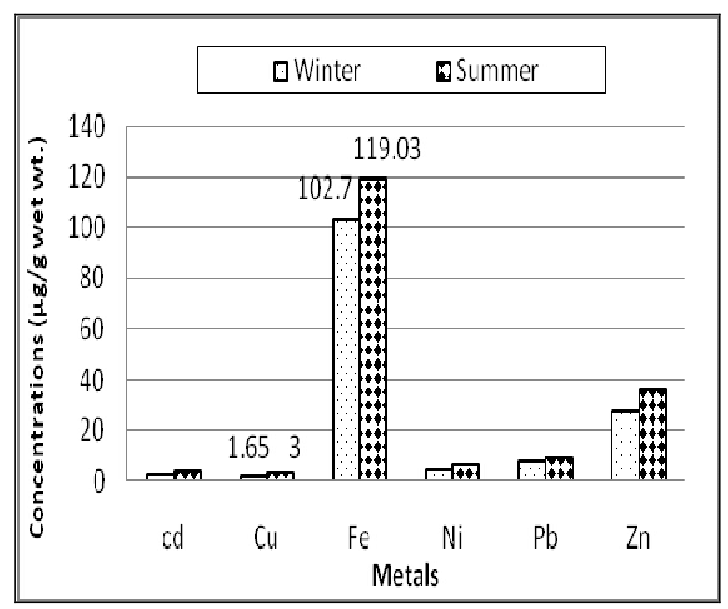

Fig. (9): Concentration of heavy metals ( $\mu \mathrm{g} / \mathrm{g}$ wet $w t)$ in the gills of Sparus aurata, collected from Mediterranean Sea Coast, Damietta Governorate, during winter and summer, 2014.

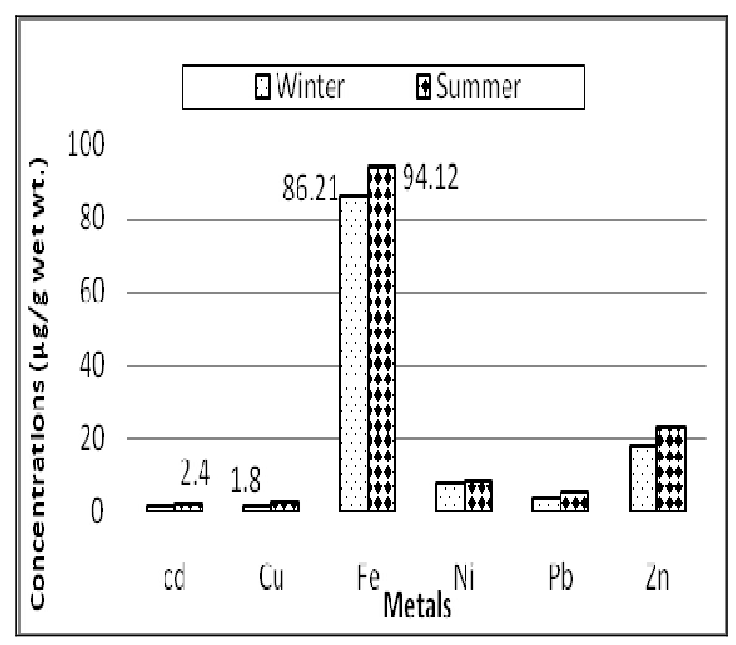

Fig. (11): Concentration of heavy metals ( $\mu \mathrm{g} / \mathrm{g}$ wet $w \mathrm{t}$ ) in the skin of Sparus aurata, collected from Mediterranean Sea Coast, Damietta Governorate, during winter and summer, 2014.

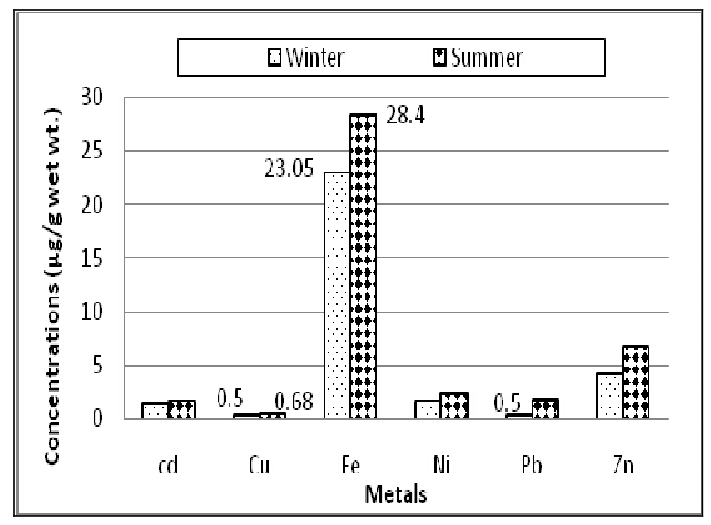

Fig. (8): Concentration of heavy metals ( $\mu \mathrm{g} / \mathrm{g}$ wet $\mathrm{wt}$ ) in the muscles of Diplodus sargus, collected from Mediterranean Sea Coast, Damietta Governorate, during winter and summer, 2014.

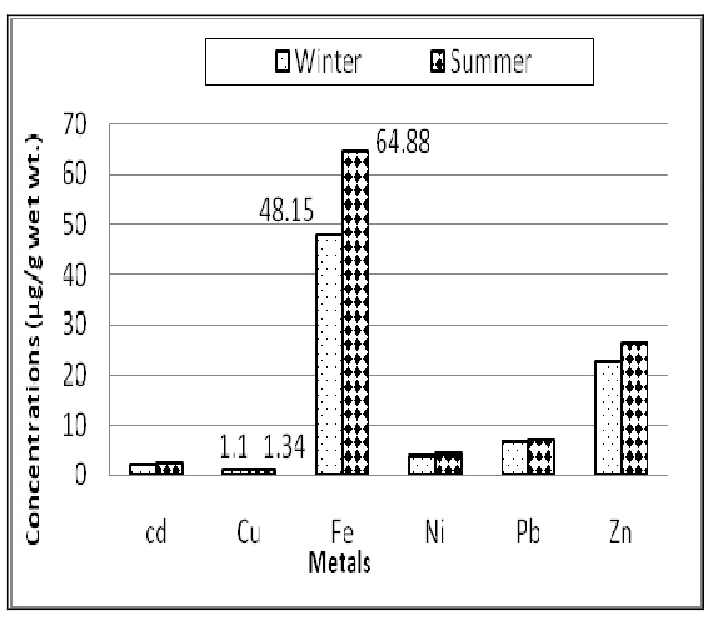

Fig. (10): Concentration of heavy metals ( $\mu \mathrm{g} / \mathrm{g}$ wet $w t)$ in the gills of Diplodus sargus, collected from Mediterranean Sea Coast, Damietta Governorate, during winter and summer, 2014.

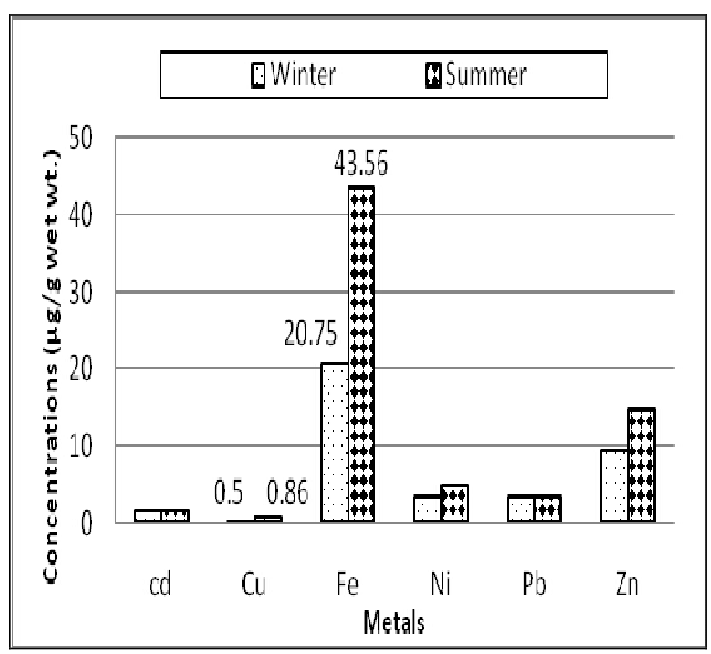

Fig. (12): Concentration of heavy metals ( $\mu \mathrm{g} / \mathrm{g}$ wet $w \mathrm{t})$ in the skin of Diplodus sargus, collected from Mediterranean Sea Coast, Damietta Governorate, during winter and summer, 2014. 
Effect of heavy metals on some physiological responses in two fish species

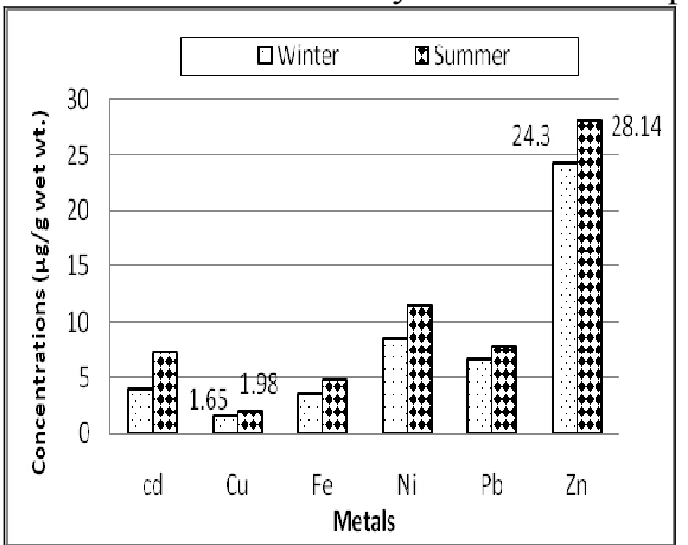

Fig. (13): Concentration of heavy metals $(\mu \mathrm{g} / \mathrm{g}$ wet $w t)$ in the bones of Sparus aurata, collected from Mediterranean Sea Coast, Damietta Governorate, during winter and summer, 2014.

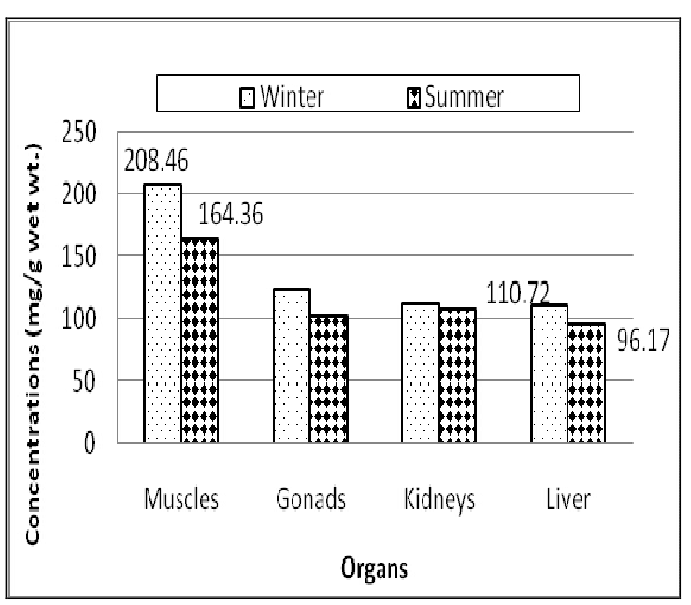

Fig. (15): Changes in total proteins $(\mathrm{mg} / \mathrm{g}$ wet $\mathrm{wt})$ in the different organs of Sparus aurata, collected from Mediterranean Sea Coast, Damietta Governorate, during winter and summer, 2014.

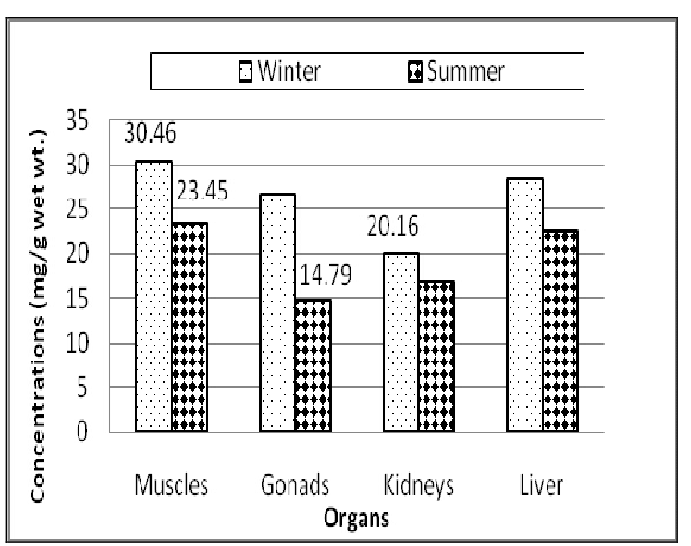

Fig. (17): Changes in total lipids ( $\mathrm{mg} / \mathrm{g}$ wet $\mathrm{wt}$ ) in the different organs of Sparus aurata, collected from Mediterranean Sea Coast, Damietta Governorate, during winter and summer, 2014.

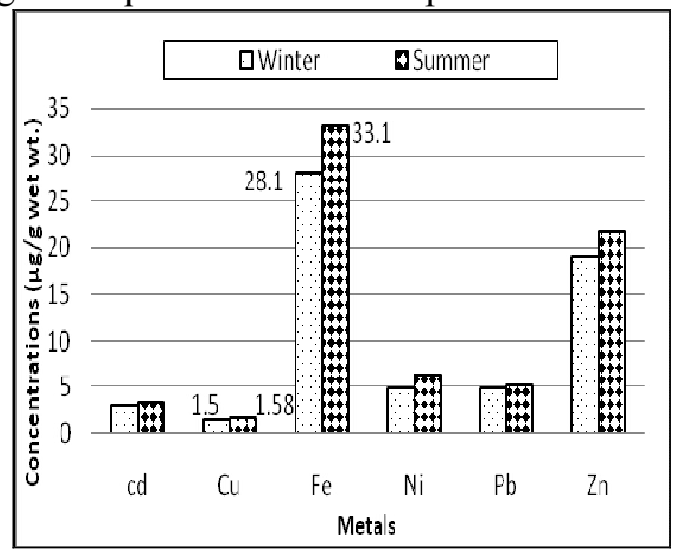

Fig. (14): Concentration of heavy metals ( $\mu \mathrm{g} / \mathrm{g}$ wet $w t)$ in the bones of Diplodus sargus, collected from Mediterranean Sea Coast, Damietta Governorate, during winter and summer, 2014.

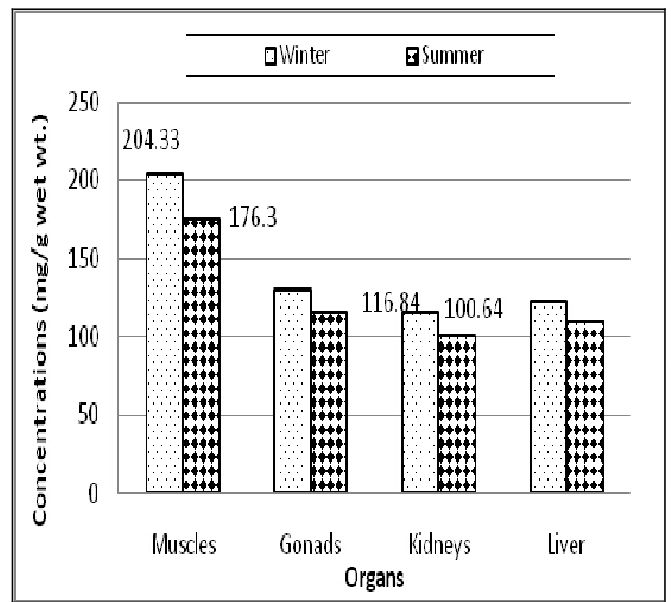

Fig. (16): Changes in total proteins $(\mathrm{mg} / \mathrm{g}$ wet wt) in the different organs of Diplodus sargus, collected from Mediterranean Sea Coast, Damietta Governorate, during winter and summer, 2014.

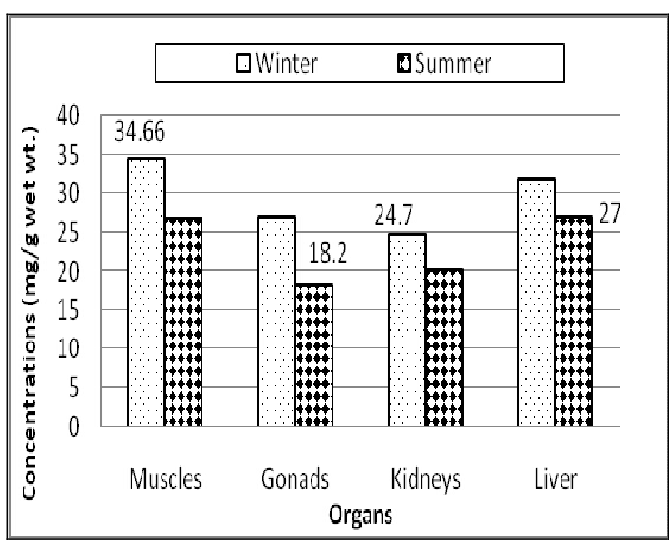

Fig. (18): Changes in total lipids ( $\mathrm{mg} / \mathrm{g}$ wet $\mathrm{wt})$ in the different organs of Diplodus sargus, collected from Mediterranean Sea Coast, Damietta Governorate, during winter and summer, 2014. 
Mohamed Hamed Ghanem

Table (3): Biochemical analysis in the different organs of Sparus aurata and Diplodus sargus collected from the Mediterranean Sea Coast; Damietta Governorate, Egypt.

\begin{tabular}{|c|c|c|c|c|c|c|c|c|c|}
\hline \multirow{2}{*}{ Parameters } & \multirow[t]{2}{*}{ Organs } & \multicolumn{2}{|c|}{ Muscles } & \multicolumn{2}{|c|}{ Gonads } & \multicolumn{2}{|c|}{ Kidney } & \multicolumn{2}{|c|}{ Liver } \\
\hline & & Winter & Summer & Winter & Summer & Winter & Summer & Winter & Summer \\
\hline \multirow{4}{*}{$\begin{array}{l}\text { Total protein } \\
\text { (mg/g wet wt.) }\end{array}$} & & 208.46 & 164.36 & 124.76 & 102.40 & 112.16 & 108.30 & 110.72 & 96.17 \\
\hline & & \pm 15.90 & \pm 8.40 & \pm 22.50 & \pm 13.42 & \pm 7.80 & \pm 8.60 & \pm 9.50 & \pm 12.40 \\
\hline & & 204.33 & 176.30 & 130.42 & 116.88 & 116.84 & 100.64 & 122.60 & 109.70 \\
\hline & & \pm 10.56 & \pm 17.46 & \pm 9.96 & \pm 12.50 & \pm 18.20 & \pm 6.55 & \pm 5.30 & \pm 4.46 \\
\hline \multirow{4}{*}{$\begin{array}{l}\text { Total lipids } \\
\text { (mg/g wet wt.) }\end{array}$} & & 30.46 & 23.45 & 26.70 & 14.79 & 20.16 & 16.88 & 28.60 & 22.63 \\
\hline & & \pm 4.36 & \pm 6.40 & \pm 9.47 & \pm 7.90 & \pm 6.20 & \pm 2.49 & \pm 4.54 & \pm 4.76 \\
\hline & & 34.66 & 26.75 & 26.90 & 18.20 & 24.70 & 20.33 & 31.76 & 27.00 \\
\hline & & \pm 2.40 & \pm 7.30 & \pm 7.94 & \pm 7.30 & \pm 4.72 & \pm 1.62 & \pm 7.13 & \pm 7.45 \\
\hline \multirow{4}{*}{$\begin{array}{c}\text { ASAT } \\
\text { (U/g wet wt.) }\end{array}$} & & 306.17 & 336.76 & 340.68 & 480.26 & 312.50 & 460.44 & 320.60 & 530.22 \\
\hline & & \pm 27.56 & \pm 20.17 & \pm 12.88 & \pm 8.46 & \pm 13.67 & \pm 9.76 & \pm 16.50 & \pm 4.76 \\
\hline & & 248.58 & 302.77 & 312.58 & 425.32 & 298.34 & 348.30 & 304.60 & 476.36 \\
\hline & & \pm 18.33 & \pm 24.00 & \pm 17.89 & \pm 10.88 & \pm 20.56 & \pm 8.70 & \pm 14.36 & \pm 7.46 \\
\hline \multirow{4}{*}{$\begin{array}{c}\text { ALAT } \\
\text { (U/g wet wt.) }\end{array}$} & & 218.53 & 267.74 & 330.12 & 364.20 & 324.32 & 318.47 & 300.78 & 338.40 \\
\hline & & \pm 17.82 & \pm 22.41 & \pm 24.70 & \pm 15.63 & \pm 14.46 & \pm 14.78 & \pm 40.56 & \pm 16.72 \\
\hline & Dinlodus saraus & 207.17 & 235.36 & 305.72 & 342.62 & 308.40 & 312.77 & 304.60 & 325.61 \\
\hline & & \pm 14.76 & \pm 23.44 & \pm 19.30 & \pm 26.10 & \pm 32.60 & \pm 13.47 & \pm 20.46 & \pm 5.63 \\
\hline
\end{tabular}

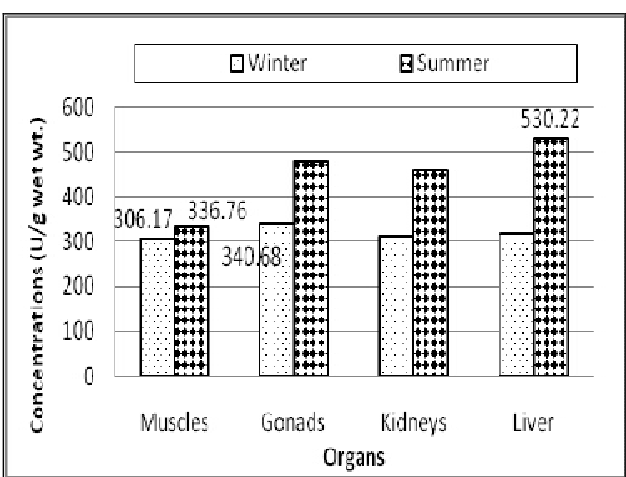

Fig. (19): Changes in ASAT (U/g wet wt) in the different organs of Sparus aurata, collected from Mediterranean Sea Coast, Damietta Governorate, during winter and summer, 2014.

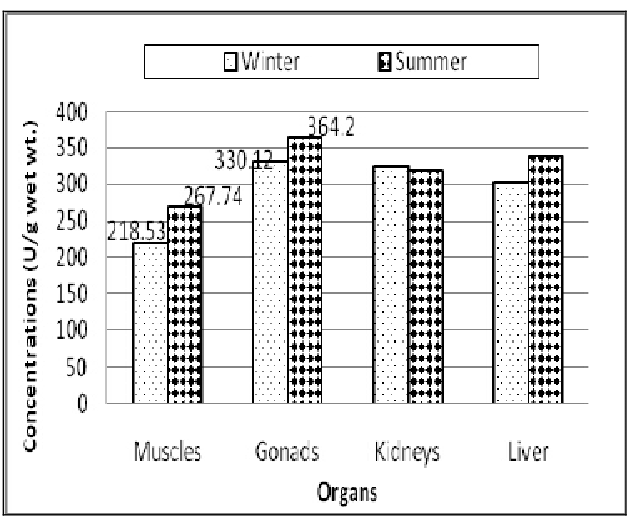

Fig. (21): Changes in ALAT (U/g wet wt) in the different organs of Sparus aurata, collected from Mediterranean Sea Coast, Damietta Governorate, during winter and summer, 2014.

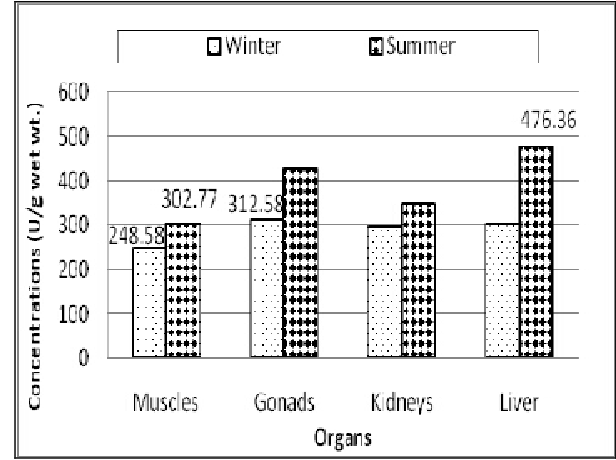

Fig. (20): Changes in ASAT (U/g wet wt) in the different organs of Diplodus sargus, collected from Mediterranean Sea Coast, Damietta Governorate, during winter and summer, 2014.

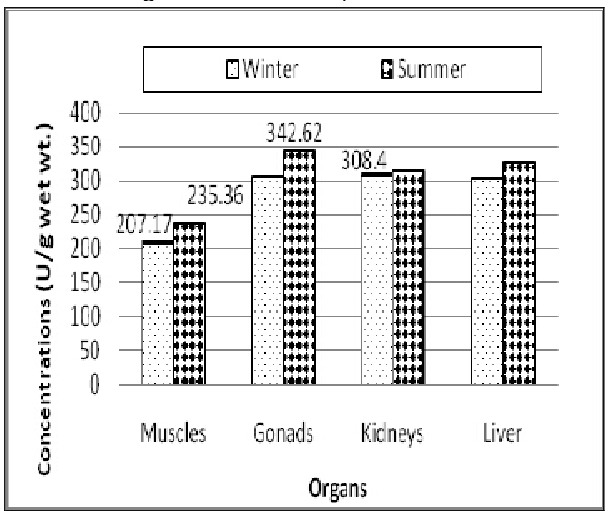

Fig. (22): Changes in ALAT (U/g wet wt) in the different organs of Diplodus sargus, collected from Mediterranean Sea Coast, Damietta Governorate, during winter and summer, 2014 


\section{REFERENCES}

Abdel-Monem, M. A.; Abd-Allah, E. A. and El-Moselhy, K. M. (1994): Level of $\mathrm{Cd}, \mathrm{Pb}, \mathrm{Cu}$, and $\mathrm{Zn}$ in Mugil seheli, from Suez Bay, 'Northern part of the Gulf of Suez, Egypt.,Bull. Nat. Inst. Oceanogr. \& Fish. A.R.E., 20(1): 69-82.

Abou El-Naga, E. H.; El-Moselhy, Kh. M. and Mohamadein, L. I. (2001): Effect of cadmium and copper on the digestive gland enzymes of the Limpet (Patella $s p$, Mollusca, Gastropoda). Journal Egypt Academy Society. Environment Development., 2(1): 29-36.

Abu El-Ella, S. M. (1996): Studies on the toxicity and bioconcentration of cadmium on grass carp, Ctenopharyngodon idella. M.Sc. Thesis, Faculty of Science, Helwan University, Egypt.

Adeyeye, E. I.; Akinyugha, N. J.; Fesobi, M. E. and Tenabe, V. O. (1996): Determination of some metals in Clarias gariepinus (cuvier and vallenciennes), Cyprinus carpio and Oreochromis niloticus fishes in poly culture freshwater pond and their environments. Aquaculture., 147: 205-214.

Ahmed, S. and Al-Ghais, S. M. (1996): Metal contents in the tissues of Lutjinus fluviflimma and Epinephelus tanvina, collected from the Arabian Gulf. Bull. Environ. Contam.\& Toxicol., 57: 957-963.

Amaraneni, S. R. (2006): Distribution of pesticides, PACs and heavy metals in prawn ponds near Kolleru Lake wetland, India. Environ. Int., 32(3):294-302.

A.P.H.A. [American Public Health and Associated] (1992): Standard methods of the examination of water and wastewater. 18th ed Washington D.C. 1015 pp.

Arellano, J. M., Blasco, J., Ortiz, J. B., Capeta-Da Silva, D., Navarro, A., Sanchez-Del Pino, M. J. and Sarasquete, C. (2000): Accumulation and histopathlogical effects of copper in gills and liver of Senegales sole, Solea senegalensis and Toad fish, Halobatrachus didactylus. Ecotoxicology and Environmental Restoration., 3 (1): 22-28.

Ashraj, W. (2005): Accumulation of heavy metals in kidney and heart tissues of Epinephelus microdon, fish from the Arabian Gulf. Environ. Monit. Assess.101(13):311-316

ATSDR (Agency for Toxic Substances and Disease Registry) (1997): Toxicological profile for Cadmium. US Department of Health and Human Services, Atlanta, GA.

Badsha, K. S. and Goldspink, C. R. (1982): Preliminary observations on the heavy metal content of 4 species of freshwater fish in North-Western Englang, UK. J.Fish Biol., 21(3): 251-268.

Badsha, K. S. \& Goldspink, C. R. (1988): Heavy metal levels in three species of fish in Tjeukemeer, a Dutch Polder lake. Chemosphere, 17 459-63.

Badmus, M. A. O.; Audu, T. O. K. and Anyata, B. U. (2007):
Removal of lead ion from industrial waste waters by activated carbon prepared from periwinkle shells (Typanotonus fuscatus), Turkish. J. Eng. Environ. Sci., 37 : 251-263.

Bailey, N. T. J. (1981): Statistical methods in biology. $2^{\text {nd }}$ Ed. (Biological Science Texts): 216pp.

Begum, G. and Vijayaragharan, S. (1995): In vivo toxicity of dimethoate on protein and transaminases in the liver tissue of fish Clarias batrachus. Bull. Environ. Contain. Toxicol., 54: 370-375.

Blaner, C.; Curitis, M. and Chan, H. (2005): Growth, nutritional composition and hematology of Artic chair (Salvelinus alpinus) exposed to toxaphene and tapeworm (Diphyllobothrium dendritiam), Archive of Environmental Contamination and Toxicology, 48: $397-$ 404.

Canli, M.; Ay, O. and Kalay, M. (1998): Level of heavy metals $(\mathrm{Cd}, \mathrm{Pb}, \mathrm{Cu}$ and $\mathrm{Ni})$ in tissues of Cyprinus carpio, Barbus capito and Chondrostoma regium from the Seyhan River. Tur. J. Zool. 22(3):149-157.

Chandra, S.; R .Ram and Singh, I. (2004): First ovarian maturity and recovery response in common carp, Cyprinus carpio after exposure to carbofuran. Journal of Environmental., Biology 25:239-249.

Chandra-Sekhar, K.; Chary, N. S.; Kamal, C.T.; SumanRaj, D. S. and Srinivas-Rao, A. (2004): Fractional studies and bioaccumulation of sediment bound heavy metals in Kolleru Lake by edible fish. Environ. Int., 29(7):1001-1008.

Clark, D. S. and Keasling, J. D. (2002): Nickel accumulation and nickel oxalate precipitation by Aspergillus niger. Applied Micro $\neg$ biology and Biotechnology, 59: 382-388.

Conacher, H. B.; Page, B.D. and Ryan, J. J. (1993): Industrial chemical contamination of foods, (Review). Food Addit. Contam., 10(10):129-143.

Cossa, D.; Auger, D. Arerty, B. Lucon, M. Masselin, P. and Noel, J. (1992): Flounder (Platichthys fiesus) muscle as an indicator of metal and organochlorine contamination of French Atlantic Coastal Water. Ambio., 12(2): 176182.

Cullen, M.; Kaufmann, R. S. and Lowery, M. S. (2003): Seasonal variation in biochemical indicators of physiological status in Euphausia superba from Port Foster, Deception Island, Antarctica.

Deep-Sea Research II (50): 1787-1798.

Dirilgen, N. (2001): Accumulation of heavy metals in freshwater: Assessment of toxic interactions. Turk. J. Chem., 25(3):173-179.

Doumas, B. T. (1975): Colourimetric determination of total protein in serum or plasma. Clin. Chem., 21(8): 11591166.

El-Sharnouby, S. A.; Moharram, U. G.; Moustafa, E.K. and 
El-Sokkary, I. A. (1986): Mercury and selenium content and relationship in barbouni, Mullus surmuletus from Alexandria water, Egypt. Bull. Inst. Oceanogr. Fish. A.R.E, 12:231-238.

El-Serafy, S. S.; El-Ezabi, M. M.; Siliem, T. A.; Shehata, M. B. and Mohammed, S. I. (2003a): Biochemical studies on Tilapia zilliii and Clarias Gariepinus, in relation to water quality criteria at different localities of the River Nile at Delta arrage. J. Egypt. Ger. Soc. Zool., 40(A): 333-349.

El-Serafy, S. S.; El-Gamal, M. M. and El-Sayed, D. S. (2003b): Seasonal variations of trace metals levels in water and the limpet, Patella caerulea, of Alexandria coast, Egypt. Egypt. J. Aquat. Boil. \& Fish., 7(4): 283312.

European Union (2002): Heavy metals in wastes, European Commission on Environment. Finney, DT., 1971. Probit Analysis. 3rd ed. Cambridge University Press. London.

Eze, L. C. (1983): Isonlorid inhibition of liver glutamate oxaloacetic transaminase from goat (Carpa hercus) . International Journal of Biochemistry., 15: 13-16.

Faria, M.; Huertes, D.; Soto, D. X.; Grimalt, J. O.; Catalan, J.; Riva, M. C. and Barata, C. (2010): Contaminant accumulation and multibiomarker responses in field collected zebra mussels (Dreissena polymorpha) and crayfish (Procambarus clarkii) to evaluate toxicological effects of industrial hazardous dumps in Ebro river (NE Spain). Chemosphere., 78: 232-240.

Farombi, E. O.; Adelowo, O. A., and Ajimoko, Y. R. (2007): Bioaccumulation of oxidative stress and heavy metal levels as indicators of environmental pollution in African Cat fish (Clarias gariepinus) from Nigeria Ogun River. Int. J. Environ. Public Health., 4(2):158-165.

Fayed, H. M.; Zaghloul, K. H.; Abdel-Monem, S. and Mohamed, H. A. (2001): Biological responses of the Nile Tilapia, Oreochromis niloticus, and the Nile catfish, Clarias gariepinus, induced by agricultural and industrial pollutants. J. Union Arab Biol., 16(A): 543-568.

Forstner, U. and Wittmann, G. T. W. (1979): Metal pollution in the aquatic environment. Springer-Verlag, Berlin, 30-61.

Ghanem, M. H. M. (2006): Ecological, physiological and histopathological studies on the grey mullet, Mugil cephalus, at different Egyptian lakes. M.Sc. Thesis, faculty of Science, Al-Azhar Univ., Cairo.,456pp

Ghanem, M. H. M. (2011): Seasonal variations of total proteins, lipids and carbohydrates in cultivated, brackish and salt water fishes with special references to their nutrient values. .Ph. D. Thesis, faculty of Science, AlAzhar Univ., Cairo., 395pp.

Gomaa, M. N. E.; Abou-Arab, A. A. K.; Badawy, A. and Naguib, K. (1995a): Distribution pattern of some heavy metals in Egyptian fish organs. Food Chemistry, 53:
$385-389$

Gomaa, M. N. E.; Badawy, A. E. and Naguib, K. (1995b): Levels of some heavy metals in different Egyptian fishes from fresh and marine environments. J. Union. Arab. Boil., 3(A): 177-195.

Gupta, A.; Rai, D. K.; Pandey, R.S. and Sharma, B. (2009): Analysis of some heavy metals in the river water, sediments and fish from Ganges at Allahabad, Environ. Monit Assess., 157 (1-4): 449-58.

Haggag, A. M; Mohamed, A. S. and Zaghloul, K. H. (1999): Seasonal effects of industrial effects on the Nile cat fish, Clarias gariepinus. J. Egyptian Germany Soc. Zool. (Comparative physiology) 28:365-391.

Ibrahim, A. M.; Bahnasawy, M. H.; Mansy, S. E. and ElFayoumy, R. I. (1999a): Distribution of heavy metals in the Damietta Nile estuary ecosystem. Egypt. J. Aquat. Boil. \& Fish., 3(4): 369-397.

Ibrahim, A. M.; Bahnasawy, M. H.; Mansy, S. E. and ElFayoumy, R. I. (1999b): Heavy metal accumulation in water, sediment and some fish in Lake Manzalah, Egypt. J. Egypt. Ger. Soc. Zool., 29(B): 43-58.

Jarup, L. (2003): Hazards of heavy metal contamination", Br. Med. Bull., 68:167-82.

Jovanovic B.; Mihaljev, E.; Maletin, S. and Palic, D. (2011): Assessment of heavy metal load in chub liver (Cyprinida: Leuciscus cephalus) from the Nisava River (Serbia), Biologica Nyssana ., 2(1):1-7

Kargin, F. and Erdem. C. (1991): Accumulation of copper in liver, spleen, stomach, intestine, gill and muscle of Cyprinus carpio. Doga. Tr. J. Zool, 15: 306-314.

Knight, J. A.; Anderson, S. and RAwie, J. M. (1972): Chemical basic of the sulfophosphovanillin reaction for estimating total serum lipid. Clin. Chem., 18: 199-202.

Kotickhoff, S. W. (1983): Pollutant sorption in environmental systems. EPA- 6001D, 80 -83, NTTS, Spring Field, VA.

Laxmi-Priya, S.; Senthilkumar, B.; Hariharan, G.; PaneerSelvam, A.; Purvaja, R. and Ramesh, R. (2011): Bioaccumulation of heavy metals in mullet (Mugil cephalus) and Oyster (Crassostrea madrasensis) from Pulicat Lake, south east cost of India, Toxicol. Ind. Health., 27(2):117-126.

Malik, N.; Biwas, A. K.; Qureshi, T. A. and Borana, K. (2010): Bioaccumulation of heavy metals in fish tissues of a freshwater lake of Bhopal. Environ. Monit. Assess., 160:267-276.

McCluggage, D. (1991): Heavy Metal Poisoning, NCS Magazine, Published by The Bird Hospital, CO, U.S.A.

Moore, M. N. and Simpson, M. G. (1992): Molecular and cellular pathology in environmental impact assessment. Aquatic Toxicology., 22: 313-322.

Nagdi, A. Z. and Shaker, N. I. (1998): Effect of water sourc- 
es on some microelements in fish farm. Egypt. J. Agric. Res., 76 (1):351-357.

Oluah, N.S. (1998): Effect of sublethal copper (11) ions on the serum transaminase activity in catfish Clarias albopunctatus,. Aquat. Sci., 13: 45-47.

Oluah, N.S. (1999): Plasma aspartate aminotransferase activity in the catfish Clarias albopunctatus exposed to sublethal zinc and mercury, Bull. Environ. Contam. Toxicol., 63: 343-349.

Ptashynski, M. D. and Klaverkamp, J. F. (2002): Accumulation and distribution of dietary nickel ion in lake whitefish, Coregonus clupeaformis. Aqua. Toxicol., 58: 249-264.

Rao, J. (2006): Biochemical alterations in euryhaline fish, Oreochromis mosambicus exposed to sublethal concentrations of organo-phosphorus insecticides monocortophos. Chemosphere., 65: 14-1820.

Rao, S. R. and Rao, P. R. (2007): Heavy metal concentrations in the sediments from Kolleru Lake, India, Indian J Environ Health.

Raymont, J. E. G. and Shields, J. (1994): Advances in water pollution research. Pergamon press. London, Oxford. $290 \mathrm{pp}$.

Reitman, S. and Frankel, S. (1957): Determination of transaminase enzymes. American J. Clin. Path., 28: 56.

Rubbi, S. F.; Muslemuddin, M.; Majeda, B.; Shamin, J. S. and Ahmed, A. T. (1985): Handling of six species of fresh fish of Bangladesh. FAO Fisheries., 317: 108122.

Said, T. O. and El-Agroudy, N. A. (2003): Concentrations of some heavy metals in the Red Sea water and their effects on the coral reef community. Egypt. J. Aquat. Boil. \& Fish., 7(2):1-17.

Salah El-Deen, M. A; Salah, R. E.; Issa, A. M. and AboHegab, S. (2000): Some metallic altrations in grass carp, Ctenopharyngodon idella, induced by exposure to mercury and zinc. Egypt. J. Aquat. Biol.\&Fish., $4(3): 21-43$.

Sancho, E.; Ferrando, M.D.; Fernandez, C. and Andreu, E. (1998): Liver energy metabolism of Anguilla anguilla, after exposure to fenitrothion. Ecotoxicol. Environ. Saf., 41(2): 168-175.

Shakoori, A. R.; Ali, T.; Iqbal, M. J. and All, S. S. (1990): Cadmium induced biochemical changes in liver and muscle of a freshwater fish, Cirrhenus mrigala. Proceedings of Pakistan Congress of Zoology, 1030710321.

Shakweer, L. M. and Abbas, M. M. (1997): Heavy metals concentration levels in some fish species of Lake Mariut and the Nozha Hydrodome, Egypt. Bull. Nat. Inst. Oceanogr. \& Fish. A.R.E., 23: 167-186.

Shalaby, A. M. (2000): Sublethal effects of heavy metals, copper, cadmium, and zinc alone or in combinations on enzymes activities of common carp, Cyprinus carpio. Egypt. J. Aquat. Boil. \& Fish., 4(2): 229-246.

Skidmore, I. T. (1964): Toxicity of zinc compounds to aquatic animals, with special references to fish. Quart. Rev. Biol., 39 (3): 227 - 248.

U.N.E.P. (1993): Preliminary Assessment of the state of pollution of the Mediterranean Sea by Zinc and Copper and their compounds and proposed measures. UNEP (OCA) / MED / WG. 66 / Inf. 3 / 19 March 1993.

Valko, M.; Morris, H. and Cronin, M. J. D. (2005): Metal toxicity and oxidative stress, Curr. Med.Chem., 12: 1161-1208.

Velez, D. and Montora, R. (1998): Arsenic speciation in manufactured seafood products: a review. J. Food Prot., 61(9):1240-1245.

Vinodhini, R. and Narayanan, M. (2008): Bioaccumulation of heavy metals in organs of fresh water fish Cyprinus carpio (Common carp). Int. J. Environ. Sci. Technol., 5(2):179-182.

Vosyliene, M. Z. and Jankaite, A. (2006): Effect of heavy metal model mixture on rainbow trout biological parameters, Ekologija. 4: 12-17.

Vutukuru, S. S. (2005): Acute effect of Hexavalent chromium on survival, oxygen consumption, hematological parameters and some biochemical profile of the Indian Major carp, Labeo rohita. Int. J. Environ. Res. Public Health., 2(3):456-462.

Wallaert, C. and Bobin, P. J. (1994): Effect of temperature variations on dietary lipid absorption and plasma lipoprotein concentrations in trout (Oncorhynchus mykiss). J. Comp. Biochem. Physiol., 109(B): 473-487.

White, A.; Fletcher, T. C. and Pope, J. A. (1986): Seasonal changes in serum lipid composition of the Plice Pleurone ctespltessa , L . J. Fish Biol., 28: 595-606.

Yacoub, A. M. and Gad, N. S (2012): Accumulation of some heavy metals and biochemical alterations in muscles of Oreochromis niloticus from the River Nile in Upper Egypt. INTERNATIO. J. OF ENVIRON.SCI. and Engineer. (IJESE)., 3: 1- 10.

Yadav, N. and Khandelwal, S. (2005): Effect of picroliv on cadmium - induced hepatic and renal damage in the rat, Hum. Exp. Toxicol., , 25, 581-91.

Yapici, G.; Timur, I. H. G. and Kaypmaz, A. (2006): Lead and cadmium exposure in children living around a coalmining area in Yatagan, Turkey", Toxicol. Ind. Health., 22: $357-62$.

Young, R. A., (2005): Toxicity Profiles: Toxicity Summary for Cadmium, Risk Assessment Information System, RAIS, University of Tennessee.

Zaghloul, K. H. (1997): Studies on the effect of water pollution along different sites of the River Nile on the survival and production of some fresh water fishes. Ph.D. Thesis, Faculty of Science, Cairo University, Egypt. 
Zaghloul, H. K. (2000). Effect of different water sources on some biological and biochemical aspect of the Nile tilapia, Oreochromis niloticus and Nile cat fish, Clarias gariepinus. Egyptian J. Zool., 34:353-377.

Zikic, R.V., Stajn, A.S., Pavlovic, S.Z., Ognjanovic, B.I. Saicic, Z.S. (2001): Activities of superoxide dismutase and catalase in erythrocytes and plasma transaminase of gold fish (Carassius auratus gibelio Bloch.) exposed to cadmium, Physiol. Res., 50: 105-111.

Zyadah, M. A. (1997): A study on levels of some heavy metals in River Nile estuary- Damietta branch, Egypt. J. Egypt. Ger. Soc. Zool., 23(A): 149-160.

الملخص العربى:

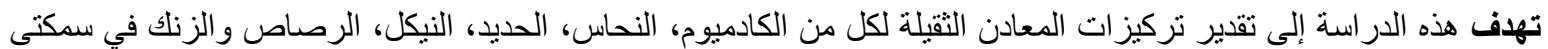

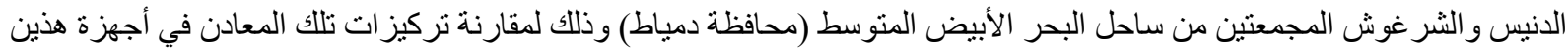

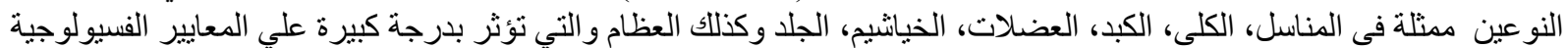

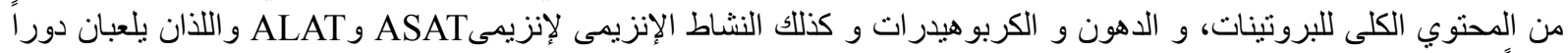

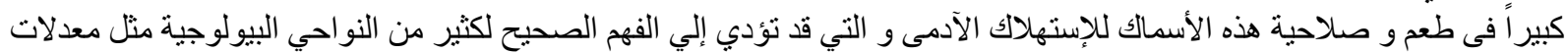
النمو، السلوك الغذائي، و نسبة الوفيات.

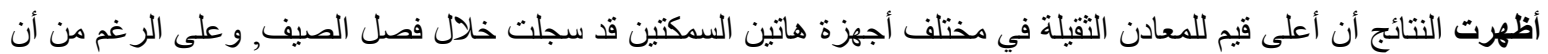

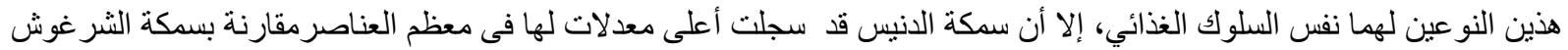

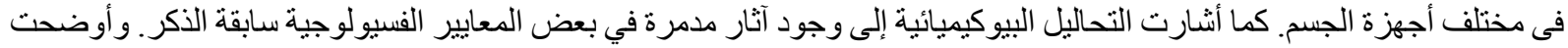
نتائج التحاليل الإحصائية وجود إختلافات معنوية بين مختلف الأجهزة و المعادن. كما أظهرت وجئ وجود زيادة فيادة كبيرة في القياسات البيوكيميائية لموسمى الصيف و الثتاء فى أجهزة الجسم المختلفة، مع وجود تفاوت طفيف بين سمكتى الدر اسة. 